\title{
Human T-cell lymphotrophic virus in solid-organ transplant recipients: Guidelines from the American society of transplantation infectious diseases community of practice
}

\author{
Daniel R. Kaul ${ }^{1}$ (D) | Tanvi S. Sharma ${ }^{2}$ | on behalf of the AST ID Community of Practice
}

${ }^{1}$ Department of Internal Medicine, Division of Infectious Diseases, University of Michigan Medical School, Ann Arbor, Michigan

${ }^{2}$ Department of Pediatrics, Division of Infectious Diseases, Boston Children's Hospital, Harvard Medical School, Boston, Massachusetts

\section{Correspondence}

Daniel R. Kaul, Division of Infectious Diseases, F4133 University Hospital South, 1500 E. Medical Center Drive, Ann Arbor, MI.

Email: kauld@umich.edu

and

Tanvi S. Sharma, Division of Infectious Disease, 333 Longwood Avenue, 5th Floor, Boston, MA.

Email: Tanvi.Sharma@childrens.harvard.edu

\begin{abstract}
These updated guidelines from the Infectious Diseases Community of Practice of the American Society of Transplantation review the diagnosis, prevention, and management of Human T-cell lymphotrophic virus 1 (HTLV)-1 in the pre- and post-transplant period. HTLV-1 is an oncogenic human retrovirus rare in North America but endemic in the Caribbean and parts of Africa, South America, Asia, and Oceania. While most infected persons do not develop disease, $<5 \%$ will develop adult T-cell leukemia/lymphoma or neurological disease. No proven antiviral treatment for established HTLV-1 infection is available. The effect of immunosuppression on the development of HTLV-1-associated disease in asymptomatically infected recipients is not well characterized, and HTLV-1-infected individuals should be counseled that immunosuppression may increase the risk of developing HTLV-1-associated disease and they should be monitored post-transplant for HTLV-1-associated disease. Currently approved screening assays do not distinguish between HTLV-1 and HTLV-2, and routine screening of deceased donors without risk factors in low seroprevalence areas is likely to result in significant organ wastage and is not recommended. Targeted screening of donors with risk factors for HTLV-1 infection and of living donors (as time is available to perform confirmatory tests) is reasonable.
\end{abstract}

\section{KEYWORDS}

complication: infectious, donors and donation: donor-derived infections, infection and infectious agents, viral: human T-lymphotropic virus

\section{1 | ETIOLOGY AND DESCRIPTION OF PATHOGEN}

Human T-cell lymphotrophic virus 1 (HTLV)-1 is an enveloped, single-stranded RNA virus from the deltaretrovirus genus of the Retroviridae family. It was the first discovered human retrovirus and the only human pathogen within the oncovirus subfamily. ${ }^{1}$ Other viruses within this subfamily include HTLV-2, bovine leukemia virus (BLV), simian T-cell leukemia virus (STLV), HTLV-3, and HTLV-4. The significant homology between HTLV-1 and STLV-1 suggests transmission of the virus between species with ultimate emergence of a separate human pathogen. HTLV-1 is considered to be the most oncogenic of human pathogens given its direct carcinogenic effect with clonal viral integrations into the progenitor cells that develop into adult T-cell leukemia/lymphoma (ALT). ${ }^{2}$ Although the overall rates of HTLV-1 infection worldwide are low, carriers have a 5\%-10\% risk of development of ATL over their lifetime, which is higher than the malignant potential associated with infection by other oncogenic viruses such as human papillomavirus or human herpesvirus-8. HTLV-1 carries a unique region different from other retroviruses which encode for regulatory proteins important for viral pathogenesis. HTLV-1 establishes latent infection in lymphocytes and infection persists for 
life. Unlike HTLV-1, the link between HTLV-2 and human disease is uncertain, although there have been occasional case reports of neurological disease, inflammatory disorders, and leukemia in infected patients. ${ }^{3}$ Thus at present, for the purpose of organ donation, HTLV-2 is not considered a human pathogen and organs from HTLV-2-positive donors are generally not considered to present an increased risk of donor-derived disease compared to organs from HTLV-2-negative donors. This guideline focuses on HTLV-1 infection.

\section{2 | EPIDEMIOLOGY AND RISK FACTORS}

Human T-cell lymphotrophic virus 1 is endemic in the Caribbean, parts of South America (highest rates reported in Brazil, Peru, Ecuador, and Venezuela), West Africa, Asia (particularly Southwestern Japan), and Oceania. In most areas of high endemicity, $2 \%-6 \%$ of adults are infected, although rates as high as $50 \%$ have recently been reported in some Australian aboriginal communities. ${ }^{4,5}$ Infection is much less common in North America. For example, in the United States (US), 0.035\%-0.046\% of blood donors are infected with HTLV-1 or HTLV-2. ${ }^{6}$ Among potential organ donors in France and the United States, similarly low rates of HTLV-1 (0.03\%-0.067\%) have been reported. ${ }^{7,8}$ Nonetheless, areas of focal higher seroprevalence may exist in countries with very low overall rates of HTLV-1. In endemic areas, breastfeeding is the predominant mode of transmission, ${ }^{5}$ but transplacental transmission as well as transmission at the time of delivery also occur. ${ }^{10}$ HTLV-1 may be transmitted via intravenous drug use, sexual intercourse (inefficiently), solid-organ transplantation (SOT), and transfusion of cell-containing blood products (14.4\%-47.3\% of recipients). ${ }^{11,12}$ HTLV-2, in contrast, is primarily found in intravenous drug users and sexual contacts of infected persons and is endemic in some indigenous populations of North, Central, and South America, and in West and Central Africa.

\section{3 | CLINICAL MANIFESTATIONS}

While most patients remain asymptomatic, following a prolonged period of latency (typically years to decades) $2 \%-5 \%$ of infected patients develop adult T-cell leukemia/lymphoma (ATL). In Southwestern Japan, $75 \%$ of Non-Hodgkins Lymphoma (NHL) is ATL. ${ }^{13}$ In addition to ATL, a small percentage of infected individuals develop severe neurological disease termed HTLV-1-associated myelopathy/tropical spastic paraparesis (HAM/TSP). Other inflammatory disorders (eg, Sjogren's syndrome, uveitis, interstitial pneumonitis), and less severe neurological disease have also been associated with HTLV-1. Children with vertically transmitted HTLV-1 may develop an infective dermatitis characterized by an exudative, eczematous rash early in life and complicated by bacterial superinfection. Nearly half of these children may go on to develop HAM/ TSP. $^{14}$ While some antiretroviral compounds demonstrate in vitro activity, no effective antiviral therapy has been demonstrated for established HTLV-1 infection.

\section{1 | Recipients positive pre-transplantation}

The effect of immunosuppression on the natural history of HTLV-1 is not well defined as very few cases have been described. This is an important issue in determining the safety of organ transplantation in HTLV-1-positive recipients. Case series from Japan describe 35 HTLV-1-positive kidney recipients with long-term follow-up; no HTLV-1 disease occurred. ${ }^{15-17}$ In contrast, a series of patients with post-transplant lymphoproliferative disease (PTLD) describes the development of HTLV-1-associated ATL in five renal transplant recipients (unknown if all cases were infected pre-transplant) with death occurring in 4/5 patients. ${ }^{18}$ Among 26 HTLV-1-positive living donor liver recipients, 4 (15\%) developed ATL with fatal outcomes in all cases. ${ }^{19}$ Although there are only a limited number of published reports describing HTLV-1-associated outcomes in SOT recipients who were seropositive prior to transplantation, based on the existing data overall survival does not seem to differ between HTLV-1positive and HTLV-1-negative recipients.

\section{2 | Donor-derived HTLV-1 infection}

From 1999 to 2009 (when the requirement to screen SOT recipients for HTLV-1 in the US was eliminated), 162 HTLV 1/2 screen-positive organs were transplanted in the United States with no HTLV-1-associated disease described in recipients. ${ }^{8,20,21}$ In virtually all cases, however, confirmatory tests were not performed on donors and analysis based on the performance of the HTLV-1/2 screening assay in a low seroprevalence population indicates that most of these donors had HTLV-2 or a false-positive screening assay. ${ }^{8}$ Further, the OPTN database tracks malignancy but not neurological outcome. Thus, the absence of reports of HTLV-1-associated disease in this population does not indicate that true-positive HTLV-1 organs can be safely transplanted.

Proven HTLV-1 transmission from seropositive donors to seronegative recipients has historically been described without known development of disease. ${ }^{19-24}$ Recently, however, cases of proven or probable donor to recipient transmission of HTLV-1 and resulting disease have been increasingly reported. In most cases, HTLV-1-associated HAM developed between 3 months and 4 years post-transplantation. ${ }^{25-30}$ Case reports have generally been from areas with higher rates of HTLV-1 infection, but at least one case occurred in the US and involved a donor from the Dominican Republic. ${ }^{29}$ A recent larger study of renal transplant recipients in Japan, an HTLV-1 endemic region, demonstrated alarming findings upon retrospective review of transplant recipients years post-transplantation. ${ }^{31}$ This study reported outcomes of 99 recipients out of 180 transplantations in which the donor, recipient, or both were known to be HTLV-1-positive at the time of transplant. Among recipients who were HTLV-1-negative and received their organ from an HTLV-1-positive donor, 87\% were confirmed to have seroconversion post-transplant and HAM developed in $40 \%$, demonstrating a substantially higher risk of disease compared to recipients who were already HTLV-1-positive 
prior to transplant. Similar to previous reports, the median time to development of HAM in this cohort was 3.8 years. ${ }^{31}$ This study emphasizes the need to consider donor screening when donors are from an HTLV-1 endemic region, particularly when recipients are unlikely to be infected. While in some cases, rapid development of HAM has been observed post-transplant, and it is difficult to compare the anticipated time to development of disease from donor-derived infection with that of natural infection in otherwise healthy individuals. Even less clear is the association between HTLV-1-positive donors and the development of ATL in seronegative recipients. Rare cases of ATL have been reported in SOT recipients, but in many cases the recipients themselves were HTLV-1-positive prior to transplantation and the malignant cells reflected recipient origin of HTLV-1 infection. ${ }^{17,18}$ Given the prolonged time to development of ATL among otherwise healthy individuals who are HTLV-1-positive, and the very limited long-term follow-up data to evaluate such outcomes in SOT recipients, characterizing the risk of development of ATL in HTLV-1-negative SOT recipients with seropositive donor organs is challenging.

\section{DIAGNOSTIC STRATEGIES}

\section{1 | Laboratory diagnosis of HTLV-1}

Enzyme-linked immunosorbent assays (EIA) are currently used as screening tests for HTLV-1/2. These tests do not distinguish between HTLV-1 and HTLV-2. Further, diagnosis of HTLV-1 infection is a two-step process requiring a confirmatory assay. The most commonly used confirmatory assays include Western Blot and line immunoassays. Depending on the assay design and the results in a particular patient, these confirmatory immunoassays may distinguish between HTLV-1 and HTLV-2. Polymerase chain reaction (PCR) tests may also be useful to confirm infection (particularly in the case of an indeterminate confirmatory test) and can distinguish between infection with HTLV-1 and HTLV-2. As plasma viremia is not prominent in HTLV-1 infection, PCR tests are best performed on peripheral blood mononuclear cells (PBMCs). In some studies, however, PCR is less sensitive than serological methods for the diagnosis of HTLV-1/2, and may be even lower for HTLV-2. ${ }^{32}$ Both Abbott and Avioq produce FDA-approved HTLV-1/2 screening tests that are indicated for screening of blood donors, organ donors, and for clinical diagnosis of HTLV infection; the MP Diagnostics HTLV Blot 2.4 is the only FDA-approved confirmatory test with an indication for use as a supplemental, specific test to confirm repeatedly reactive results by FDA-approved screening tests in human serum and plasma samples. The HTLV Blot 2.4 test is not intended for use in medical diagnosis. In most settings, confirmatory results are not available in a time frame adequate to make decisions regarding deceased donor organ donation.

Screening EIA tests are highly sensitive but have poor positive predictive value when applied to a low seroprevalence population. For example, using the Abbott HTLV-I/II EIA assay (now discontinued) 15215 blood donors, 51 (0.35\%) were repeatedly reactive; only
10 of these had positive confirmatory tests and only 4 had confirmed HTLV-1. Thus, only 4/51 (7.9\%) of screen-positive patients had confirmed HTLV-1 infection. ${ }^{33}$ In patients with medical conditions unrelated to HTLV-1/2, higher rates of positive screens are obtained (26/639), but only $3 / 26$ were confirmed to have HTLV-1 infection. ${ }^{33}$ Likewise, among potential organ donors, HTLV-1 infection could not be confirmed in the majority of screen-positive donors. ${ }^{8}$

\subsection{Recommendations}

- Whenever possible, HTLV-1/2 screen-positive results should be confirmed with western blot, line immunoassay, or polymerase chain reaction (strong, low).

\section{5 | TREATMENT}

Currently, no proven medical treatment for asymptomatic carriers of HTLV-1 exists. Antiretroviral effective in HIV infection have achieved mixed results at best in reducing HTLV proviral loads (the typically stable amount of virus present in infected cells), ${ }^{34-38}$ and this is unsurprising as viral replication is sustained by cellular division rather than highly active viral production. ${ }^{35}$ Other proposed treatments for asymptomatic carriers or patients with HAM/TSP include corticosteroids, alpha interferon, anti-CD25 monoclonal antibody, cyclosporine, and valproic acid which increases viral expression theoretically leading to enhanced immune surveillance. ${ }^{35}$ Overall, treatment is focused on management of sequelae of HTLV-1 infection-namely ATL and HAM/TSP-in carriers who develop HTLV-1associated disease.

\section{$5.1 \mid$ Recommendations}

- No specific proven treatment for asymptomatic HTLV-1 infection is currently available (weak, very low).

\section{6 | PREVENTION}

\section{1 | Donor screening}

As a result of both the planned discontinuation of the Abbott HTLV-I/ II assay in 2009 and concern regarding the high false-positive rate of available assays, an analysis of universal HTLV-1 screening in deceased donors was undertaken. This suggested that 167-227 uninfected organs were discarded yearly due to false-positive screening tests. ${ }^{8} \mathrm{~A}$ separate analysis estimated that in a low prevalence population the ratio of false-positive to true-positive HTLV-1 screening assays was 40:1. ${ }^{39}$ Based on these considerations, the requirement for HTLV-1 screening of deceased donors was removed by OPTN/ UNOS in 2009 
In general, OPTN/UNOS policy limits recommendations for laboratory testing to assays approved by the FDA for purpose of donor screening. Currently, 3 assays are FDA-approved for screening of potential organ donors in the United States and one assay is approved for confirmatory testing. ${ }^{40}$ The characteristics of each assay are described in Table 1. A major limitation to donor screening is the inability of any licensed screening test to distinguish HTLV-1 from HTLV-2 and the practical challenges to completing a confirmatory test prior to organ donation. Nonetheless, recent reports-including one from the US-describe additional cases of proven or probable donor-derived HTLV-1 with a high incidence of HAM/TSP in HTLV-1-negative recipients of HTLV-1-positive donors. ${ }^{25-31}$ The highest risk situation appears to be seronegative recipients of seropositive donors. ${ }^{31}$ Further, given the impact of globalization and increasing migration of individuals from around the world, there are geographic differences in the seroprevalence of HTLV-1 within the US. ${ }^{9}$ Targeted screening of deceased donors at increased risk for HTLV-1 must be balanced against the poor specificity of available screening tests and the risk of discarding uninfected organs. Several of the recent reports have highlighted transmission and HTLV-1-associated disease from living donors. ${ }^{26,28,30}$ In this circumstance, additional time is available to conduct confirmatory testing and avoid unnecessary organ wastage.

\section{2 | Follow-up of recipients at risk for donor- derived HTLV-1}

The optimal management and follow-up of recipients receiving organs from donors proven or suspected to have HTLV-1 is unknown. In cases of screen-positive donors, every effort should be made to perform confirmatory tests on stored donor samples to determine if the donor is actually HTLV-1-infected. Recipients of HTLV-2-positive donors or those with negative confirmatory assays do not require specific follow-up. If the donor is proven to have HTLV-1 or confirmatory tests cannot be done or are indeterminate, periodic testing for HTLV-1 using both serological (may have low sensitivity in immunosuppressed patients) and nucleic acid-based testing on the recipient is indicated. Testing quarterly for 1 year and then biannually for 1 year would be a reasonable approach. While therapeutic options are uncertain, recipients would benefit from knowing their HTLV-1 status to prevent secondary (sexual or breastfeeding) transmission (see below). Further, HTLV-1 viral loads are higher in patients with neurological disease than in asymptomatic carriers, ${ }^{41,42}$ and patients with donor-derived infection might benefit from viral load guided modulation in their immunosuppression. While HTLV-1 viral loads appear to be maintained by cell division rather than production of new virus and tend to remain stable, this may not be true in immunosuppressed patients.

Standardized clinical monitoring for complications of HTLV-1 infection is not well established. ATL may present with any of a number of clinical features, including generalized adenopathy, cutaneous lesions, hypercalcemia, bony lesions, and/or isolated peripheral blood abnormalities/leukemia. HAM/TSP is equally variable in clinical manifestation, and may present with stiff gait, spasticity and lower extremity weakness, back pain, urinary incontinence, impotence, paresthesias, decreased sensation (particularly for posterior column modalities such as vibratory sense), and upper motor neuron signs. $^{43}$

\section{3 | Risk to staff}

Human T-cell lymphotrophic virus 1 is spread by cell-associated virus, rather than by cell-free virus and body fluids, and is transmitted by blood products, sexual activity, and breastfeeding. As with other blood-borne pathogens, the greatest risk for healthcare workers caring for an HTLV-1-infected patient is accidental inoculation via contaminated sharps. While transmission of both HTLV-1 and HTLV-2 in the occupational setting have been reported, ${ }^{44,45}$ in another report no seroconversions occurred among 34 healthcare workers exposed

\begin{tabular}{|ll}
\hline Assay & Comments \\
\hline Abbott HTLV-I/II & - Practical for OPO use \\
& - No longer available in the United States \\
& - Does not distinguish between HTLV-1 and HTLV-2 \\
\hline Abbott Prism HTLV-I/ & - Designed for large scale use (blood produce donor screening) \\
II & - Not practical in most OPO laboratories \\
& - Requires significant investment in expensive equipment and \\
& - - Deagents \\
Avioq HTLV-I/II & - Approved forstinguish between HTLV-1 and HTLV-2 \\
Microelisa System & - Recently approved (March 2012) and practicality for OPO use \\
& - unproven \\
MP Diagnostics HTLV & - Approved not distinguish between HTLV-1 and HTLV-2 \\
Blot 2.4 & test result \\
& - May distinguish HTLV-1 from HTLV-2 \\
\hline
\end{tabular}

Abbreviations: HTLV, human T-cell lymphotrophic virus; OPO, organ procurement organizations
TABLE 1 FDA-approved HTLV-1/2 screening assays 
by puncture wounds. ${ }^{46}$ No data exist on appropriate prophylaxis for individuals exposed to HTLV. While some have recommended the use of antiretroviral agents in settings of severe exposure (eg, zidovudine/lamivudine/raltegravir), ${ }^{38,47,48}$ the CDC and other US agencies do not recommend post-exposure prophylaxis due to the lack of available data. As with other blood-borne pathogens, universal, standard precautions and scrupulous sharps safety are considered sufficient for the prevention of HTLV acquisition.

\section{4 | Risk to others (Secondary transmission)}

In the non-occupational setting, transmission may occur horizontally (usually through sexual activity, or through sharing of injection drug needles) or vertically (mother-to-child, almost entirely through breastfeeding). These can be issues for a recipient who received an HTLV-1-infected or possibly infected organ, or for an HTLV-uninfected SOT recipient who may be entering a sexual relationship with an HTLV-infected partner. The effects of immunosuppression on the risk of acquisition of HTLV are not understood, though at least one animal model suggests that cyclosporine at the time of HTLV-1 infection increased the viral set point and might result in increased risk of the development of HTLV-1-associated disease. ${ }^{49}$ For the HTLV-1-infected SOT recipient, a few general comments apply with respect to transmission. Sexual transmission of HTLV-1 can be prevented effectively with condom use and other safer sex practices (as recommended for prevention of HIV transmission). Transmission by (injection) needles can be minimized by employment of sterile needles with each use and by avoidance of sharing of needles and other potentially contaminated equipment. Vertical transmission can be decreased by avoidance of breastfeeding (particularly in the US and other resource-rich settings, where breast milk alternatives are available).

Recommendations (see Table 2)

- While the impact of immunosuppression on the natural history of HTLV-1 is not fully understood, persons seropositive for HTLV-1 can be considered for transplantation. Given that these recipients may face a higher (but difficult to quantify) risk of serious disease (ATL and HAM/TSP), information regarding this risk should be provided to HTLV-1-positive potential recipients as part of the informed consent process (strong, low).

- In low seroprevalence areas (like North America), only in extreme circumstances should confirmed HTLV-1 seropositive donors be used. As routine HTLV-1 screening of deceased donors is no longer performed by most OPOs, the most likely scenario would be a living donor in whom confirmatory testing could be performed or a high-risk deceased donor in whom screening and confirmatory testing is performed (strong, moderate).

- Due to the low seroprevalence of HTLV-1 in the United States and the poor positive predictive value of screening HTLV-1/2 assays in this population, routine screening of all deceased donors is not recommended (strong, moderate).
- Individual OPOs with higher prevalence populations (eg, a high proportion of immigrants from endemic countries) could consider targeted or universal screening. However, even in these higher risk donors, most screen-positive donors likely will not have HTLV-I. If access to rapid confirmatory testing is available, this would decrease the number of uninfected organs discarded (weak, low).

- Living donors with epidemiological risk factors for HTLV-1 should be screened for HTLV-1 as in this situation adequate time to perform confirmatory testing is available (strong, low).

- Recipients of confirmed or suspected HTLV-1-infected organs should undergo periodic monitoring using both serological and nucleic acid-based testing (quarterly for 1 year then every 6 months for 1 year) (strong, low).

- Since the time to development of HTLV-1-associated complications in immunosuppressed patients post-transplantation is unknown, follow-up of seropositive SOT recipients should include regular clinical monitoring for complications of infection, including ATL and HAM/TSP (focusing on the skin, lymph nodes, hematologic system, and neurological system), in conjunction with routine post-SOT follow-up care (strong, low).

- Solid-organ transplantation recipients who are HTLV-infected (or received potentially infected organs) should be counseled about risks of transmission to others, including how to minimize those risks (strong, low).

- Solid-organ transplantation recipients who are at risk for acquiring HTLV-1 should be counseled on modes of transmission and how to minimize the risk of acquisition. In general, these recommendations follow those for other viruses such as HIV or hepatitis C (strong, low).

- Standard, universal precautions should be employed when providing care to patients with HTLV-1 infection (strong, low).

- There is insufficient evidence to recommend occupational postexposure prophylaxis for those who are exposed to HTLV-1 (weak, very low).

\section{7 | FUTURE RESEARCH}

A number of important issues regarding HTLV-1/2 and SOT recipients remain undefined. Perhaps most importantly, since most donors in the US are not screened for HTLV-1, the transplant community should monitor for cases of ATL or HAM in recipients that could represent donor-derived infection. The handful of donor-derived cases reported combined with local communities in the US with increased prevalence of HTLV-1, highlights the need for improved assays that are practical for use in OPOs and can efficiently distinguish HTLV-1 from HTLV-2 if targeted deceased donor screening is to be fully endorsed. We also need to better understand the effect of immunosuppression on the natural history of asymptomatic HTLV-1 infection, and additional case series from endemic regions are needed. Finally, further studies are needed to better define the role of antiretrovirals as post-exposure prophylaxis. 
TABLE 2 Summary of recommendations

\begin{tabular}{|c|c|c|c|}
\hline \multicolumn{2}{|l|}{ Recommendation } & \multirow{2}{*}{$\begin{array}{l}\text { Level of Evidence } \\
\text { (Strong, low) }\end{array}$} & \multirow{2}{*}{$\begin{array}{l}\text { Comment } \\
\text { Most screen-positive donors or recipients will } \\
\text { not have HTLV-1. }\end{array}$} \\
\hline Diagnosis & $\begin{array}{l}\text { Whenever possible, screen-positive results } \\
\text { should be confirmed with western blot, line im- } \\
\text { munoassay, or PCR }\end{array}$ & & \\
\hline Treatment & $\begin{array}{l}\text { No specific proven treatment of asymptomatic } \\
\text { HTLV-1 infection is available }\end{array}$ & (Weak, very low) & $\begin{array}{l}\text { Proposed treatments include corticosteroids, } \\
\text { alpha interferon, anti-CD25 monoclonal anti- } \\
\text { body, cyclosporine, and valproic acid. }\end{array}$ \\
\hline Prevention & $\begin{array}{l}\text { In low seroprevalence areas, confirmed HTLV-1- } \\
\text { positive donors should only be used in extreme } \\
\text { circumstances. }\end{array}$ & (Strong, moderate) & $\begin{array}{l}\text { While routine screening is no longer required, } \\
\text { in some circumstances (eg, living donors) con- } \\
\text { firmed serostatus may be available. }\end{array}$ \\
\hline \multirow[t]{3}{*}{ Donor screening } & $\begin{array}{l}\text { Routine screening of all deceased donors for } \\
\text { HTLV-1 is not recommended }\end{array}$ & (Strong, moderate) & $\begin{array}{l}\text { In low seroprevalence areas, most screen-posi- } \\
\text { tive donors do not have HTLV-1 resulting in } \\
\text { significant wastage of uninfected organs. }\end{array}$ \\
\hline & $\begin{array}{l}\text { Individual OPO's with higher prevalence popula- } \\
\text { tions (eg, immigrants from high prevalence } \\
\text { countries) could consider targeted screening. }\end{array}$ & (Weak, low) & $\begin{array}{l}\text { While a positive screening test in a higher risk } \\
\text { donor is more likely to represent a true-positive, } \\
\text { even in this circumstance if a timely confirma- } \\
\text { tory test cannot be performed most screen- } \\
\text { positive donors will likely not have HTLV-1. }\end{array}$ \\
\hline & $\begin{array}{l}\text { Living donors with epidemiological risk factors } \\
\text { (eg, previous residence in endemic area) should } \\
\text { be screened as time frame allows for perfor- } \\
\text { mance of confirmatory testing. }\end{array}$ & (Strong, low) & $\begin{array}{l}\text { Reports of donor-derived HTLV-1 disease justify } \\
\text { testing in higher epidemiological risk donors } \\
\text { when adequate time for confirmatory testing is } \\
\text { available. }\end{array}$ \\
\hline \multirow[t]{5}{*}{ Recipient issues } & $\begin{array}{l}\text { Periodic testing (quarterly for } 1 \text { y and then } \\
\text { biannually for } 1 \text { y) with both PCR and serology } \\
\text { should be performed on recipients of proven or } \\
\text { suspected HTLV-1-infected donors. }\end{array}$ & (Strong, low) & $\begin{array}{l}\text { While no proven intervention is available, } \\
\text { recipients with the potential for donor-derived } \\
\text { HTLV-1 should be made aware of the risk of } \\
\text { secondary transmission (sexual or breastfeed- } \\
\text { ing) and investigational treatments/prophylaxis } \\
\text { could be considered. }\end{array}$ \\
\hline & $\begin{array}{l}\text { HTLV-1 seropositive individuals should not be } \\
\text { excluded from transplantation, but informed } \\
\text { consent should be obtained. }\end{array}$ & (Strong, low) & $\begin{array}{l}\text { Reports demonstrate good outcomes without } \\
\text { the development of HTLV-1 disease after } \\
\text { transplantation. Immunosuppression may speed } \\
\text { the development of HTLV-1 disease; HTLV-1 } \\
\text { related deaths have been reported after organ } \\
\text { transplantation. }\end{array}$ \\
\hline & $\begin{array}{l}\text { Follow-up of HTLV-1-positive SOT recipients } \\
\text { should include regular clinical monitoring for } \\
\text { complications of infection, including ATL and } \\
\text { HAM/TSP. }\end{array}$ & (Strong, low) & $\begin{array}{l}\text { Investigational (HAM/TSP) and standard (ATL) } \\
\text { treatments could be considered. }\end{array}$ \\
\hline & $\begin{array}{l}\text { SOT recipients who are HTLV-1-infected (or } \\
\text { received potentially infected organs) should be } \\
\text { counseled about risks of transmission to others, } \\
\text { including how to minimize those risks }\end{array}$ & (Strong, low) & $\begin{array}{l}\text { HTLV-1 can be transmitted through sexual con- } \\
\text { tact, breastfeeding, or sharing injection needles. } \\
\text { HTLV-1 cannot be transmitted through casual } \\
\text { contact. }\end{array}$ \\
\hline & $\begin{array}{l}\text { SOT recipients who are at risk for acquiring } \\
\text { HTLV-1 should be counseled on modes of } \\
\text { transmission and how to minimize the risk of } \\
\text { acquisition. In general, these recommendations } \\
\text { follow those for other viruses such at HIV or } \\
\text { hepatitis C (Category III). }\end{array}$ & (Strong, low) & $\begin{array}{l}\text { This would primarily apply to transplant recipi- } \\
\text { ents who are sexual partners of HTLV-1-in- } \\
\text { fected individuals. }\end{array}$ \\
\hline \multirow[t]{2}{*}{ Infection control } & $\begin{array}{l}\text { Standard, universal precautions should be } \\
\text { employed when providing care to patients with } \\
\text { HTLV infection }\end{array}$ & (Strong, low) & $\begin{array}{l}\text { In occupational settings, HTLV-1 transmission is } \\
\text { similar to other blood-borne viruses (HIV). }\end{array}$ \\
\hline & $\begin{array}{l}\text { There is insufficient evidence to recommend oc- } \\
\text { cupational post-exposure prophylaxis for those } \\
\text { who are exposed to HTLV-1 }\end{array}$ & (Weak, very low) & $\begin{array}{l}\text { The use of antiretrovirals immediately after } \\
\text { exposure could theoretically prevent the estab- } \\
\text { lishment of infection, but there is only in vitro } \\
\text { data to support this. }\end{array}$ \\
\hline
\end{tabular}

Abbreviations: ATL, adult T-cell leukemia; HAM/TSP, HTLV-associated myelopathy/tropical spastic paraparesis; HIV, human immunodeficiency virus; HTLV, human T-cell lymphotrophic virus; OPO, organ procurement organizations; PCR, polymerase chain reaction; SOT, solid-organ transplant. 


\section{ACKNOWLEDGEMENTS}

This manuscript was modified from the Guideline included in the $3^{\text {rd }}$ Edition of the AST Infectious Diseases Guidelines written by Daniel Kaul and John Davis and published in the American Journal of Transplantation 2013;13 (Suppl 4): 355-360, and endorsed by the American Society of Transplantation.

\section{CONFLICT OF INTEREST}

The authors have no conflicts of interest to disclose.

\section{ORCID}

Daniel R. Kaul (DD https://orcid.org/0000-0003-0990-4148

\section{REFERENCES}

1. Mahieux R, Gessain A. The human HTLV-3 and HTLV-4 retroviruses: new members of the HTLV family. Pathol Biol. 2009;57(2):161-166.

2. Tagaya Y, Gallo RC. The exceptional oncogenicity of HTLV-1. Front Microbiol. 2017;8:1425.

3. Murphy E, Roucoux D. The epidemiology and disease outcomes of human T-lymphotropic virus type II. AIDS Rev. 2004;6(3):144-154.

4. Blattner WA, Saxinger C, Riedel D, et al. A study of HTLV-I and its associated risk factors in Trinidad and Tobago. J Acquir Immune Defic Syndr. 1990;3(11):1102-1108.

5. Proietti FA, Carneiro-Proietti AB, Catalan-Soares BC, Murphy EL. Global epidemiology of HTLV-I infection and associated diseases. Oncogene. 2005;24(39):6058-6068.

6. Glynn SA, Kleinman SH, Schreiber GB et al. Trends in incidence and prevalence of major transfusion-transmissible viral infections in US blood donors, 1991 to 1996. Retrovirus Epidemiology Donor Study (REDS). JAMA. 2000;284(2):229-235.

7. Claquin J, Romano P, Noury D, et al. Human T lymphotropic virus 1-2 positive antibodies in potential organ donors in France. Transpl Proc. 1996;28(1):189-190.

8. Kaul DR, Taranto S, Alexander C, et al. Donor screening for human T-cell lymphotrophic virus 1/2: changing paradigms for changing testing capacity. Am J Transplant. 2010;10(2):207-213.

9. Tedla F, Brar A, John D, Sumrani N. Risk of transmission of human T-lymphotropic virus through transplant. Am J Transplant. 2015;15(4):1123-1124.

10. Carneiro-Proietti AB, Amaranto-Damasio MS, Leal-Horiguchi CF, et al. Mother-to-child transmission of human T-cell lymphotropic viruses-1/2: what we know, and what are the gaps in understanding and preventing this route of infection. J Pediatric Infect Dis Soc. 2014;3(Suppl 1):S24-29.

11. Manns A, Wilks RJ, Murphy EL, et al. A prospective study of transmission by transfusion of HTLV-I and risk factors associated with seroconversion. Int J Cancer. 1992;51(6):886-891.

12. Martin-Davila P, Fortun J, Lopez-Velez R, et al. Transmission of tropical and geographically restricted infections during solid-organ transplantation. Clin Microbiol Rev. 2008;21(1):60-96.

13. Aoki R, Karube K, Sugita $\mathrm{Y}$, et al. Distribution of malignant lymphoma in Japan: analysis of 2260 cases, 2001-2006. Pathol Int. 2008;58(3):174-182.

14. de Oliveira Mde F, Fatal PL, Primo JR, et al. Infective dermatitis associated with human T-cell lymphotropic virus type 1: evaluation of 42 cases observed in Bahia. Brazil. Clin Infect Dis. 2012;54(12):1714-1719.
15. Nakamura N, Tamaru S, Ohshima K, Tanaka M, Arakaki Y, Miyauchi T. Prognosis of HTLV-I-positive renal transplant recipients. Transpl Proc. 2005;37(4):1779-1782.

16. Tanabe K, Kitani R, Takahashi K, et al. Long-term results in human T-cell leukemia virus type 1-positive renal transplant recipients. Transpl Proc. 1998;30(7):3168-3170.

17. Shirai $H$, Suzuki M, Tomita $Y$, et al. Renal transplantation in patients with human T-cell lymphotropic virus type 1 . Transplant Proc. 2012;44(1):83-86.

18. Hoshida Y, Li T, Dong Z, et al. Lymphoproliferative disorders in renal transplant patients in Japan. Int J Cancer. 2001;91(6):869-875.

19. Yoshizumi T, Shirabe K, Ikegami T, et al. Impact of human $T$ cell leukemia virus type 1 in living donor liver transplantation. Am J Transplant. 2012;12(6):1479-1485.

20. Marvin MR, Brock GN, Kwarteng K, et al. Increasing utilization of human T-cell lymphotropic virus (+) donors in liver transplantation: is it safe? Transplantation. 2009;87(8):1180-1190.

21. Shames BD, D'Alessandro AM, Sollinger HW. Human T-cell lymphotrophic virus infection in organ donors: a need to reassess policy? Am J Transplant. 2002;2(7):658-663.

22. Nakamura N, Arakaki $\mathrm{Y}$, Sunagawa $\mathrm{H}$, et al. Influence of immunosuppression in HTLV-1-positive renal transplant recipients. Transpl Proc. 1998;30(4):1324-1326.

23. Remesar MC, del Pozo AE, Pittis MG, Mangano AM, Sen L, Briones L. Transmission of HTLV-I by kidney transplant. Transfusion. 2000;40(11):1421-1422.

24. Yara S, Fujita J, Date H. Transmission of human T-lymphotropic virus type I by bilateral living-donor lobar lung transplantation. J Thorac Cardiovasc Surg. 2009;138(1):255-256.

25. Gövert F, Krumbholz A, Witt K, et al. HTLV-1 associated myelopathy after renal transplantation. J Clin Virol. 2015;72:102-105.

26. Montesdeoca Andrade MJ, Correa Diaz EP, Buestan ME. HTLV-1associated myelopathy in a solid organ transplant recipient. BMJ Case Rep. 2016;2016: bcr2016215243.

27. Moreno-Ajona D, Yuste JR, Martin P, Gallego P-L. HTLV-1 myelopathy after renal transplant and antiviral prophylaxis: the need for screening. J Neurovirol. 2018;24(4):523-525.

28. Nagamine $\mathrm{Y}$, Hayashi T, Kato $\mathrm{Y}$, Horiuchi $\mathrm{Y}$, Tanahashi N. Human $\mathrm{T}$ Iymphotropic virus type-1-associated myelopathy manifesting shortly after living-donor renal transplantation. Intern Med. 2015;54(1):75-78.

29. Ramanan P, Deziel PJ, Norby SM, Yao JD, Garza I, Razonable RR. Donor-transmitted HTLV-1-associated myelopathy in a kidney transplant recipient-case report and literature review. Am J Transplant. 2014;14(10):2417-2421.

30. Tajima Y, Matsumura M, Yaguchi H, Mito Y. Two cases of human T-lymphotropic virus Type I-associated myelopathy/tropical spastic paraparesis caused by living-donor renal transplantation. Case Rep Neurol Med. 2016;2016:4203079.

31. Yamauchi J, Yamano Y, Yuzawa K. Risk of human T-cell Leukemia virus Type 1 infection in kidney transplantation. N Engl J Med. 2019;380(3):296-298.

32. Lee TH, Chafets DM, Busch MP, Murphy EL. Quantitation of HTLV-I and II proviral load using real-time quantitative PCR with SYBR green chemistry. J Clin Virol. 2004;31(4):275-282.

33. Package insert: Abbott HTLV-I/HTLV-II EIA.

34. Gout O, Gessain A, Iba-Zizen MT, et al. The effect of zidovudine on chronic myelopathy associated with HTLV-1. J Neurol. 1991;238(2):108-109.

35. Martin F, Taylor GP. Prospects for the management of human Tcell lymphotropic virus type 1-associated myelopathy. AIDS Rev. 2011;13(3):161-170.

36. Sheremata WA, Benedict D, Squilacote DC, Sazant A, DeFreitas E. High-dose zidovudine induction in HTLV-I-associated myelopathy: safety and possible efficacy. Neurology. 1993;43(10):2125-2129. 
37. Taylor GP, Goon P, Furukawa Y, et al. Zidovudine plus lamivudine in Human T-Lymphotropic Virus type-I-associated myelopathy: a randomised trial. Retrovirology. 2006;3:63.

38. Treviño A, Parra P, Bar-Magen T, Garrido C, de Mendoza C, Soriano V. Antiviral effect of raltegravir on HTLV-1 carriers. J Antimicrob Chemother. 2012;67(1):218-221.

39. Huang RC, Fishman JA. Screening of deceased organ donors: no easy answers. Transplantation. 2011;91(2):146-149.

40. Food and Drug Administration. 2012; www.fda.gov/BiologicsB loodVaccines/BloodBloodProducts/ApprovedProducts/licensedPr oductsBLAs/BloodDonorScreening/InfectiousDisease/ucm09 0707.htm.

41. Grassi M, Olavarria VN, Kruschewsky R, et al. T cell lymphotropic virus type 1 (HTLV-1) proviral load of HTLV-associated myelopathy/ tropical spastic paraparesis (HAM/TSP) patients according to new diagnostic criteria of HAM/TSP. J Med Virol. 2011;83(7):1269-1274.

42. Silva MT, Harab RC, Leite AC, Schor D, Araujo A, Andrada-Serpa MJ. Human T lymphotropic virus type 1 (HTLV-1) proviral load in asymptomatic carriers, HTLV-1-associated myelopathy/tropical spastic paraparesis, and other neurological abnormalities associated with HTLV-1 infection. Clin Infect Dis. 2007;44(5):689-692.

43. Goncalves DU, Proietti FA, Ribas J, et al. Epidemiology, treatment, and prevention of human T-cell leukemia virus type 1-associated diseases. Clin Microbiol Rev. 2010;23(3):577-589.

44. Kataoka R, Takehara N, Iwahara Y, et al. Transmission of HTLV-I by blood transfusion and its prevention by passive immunization in rabbits. Blood. 1990;76(8):1657-1661.
45. Menna-Barreto M. HTLV-II transmission to a health care worker. Am J Infect Control. 2006;34(3):158-160.

46. Amin RM, Jones $B$, Rubert $M$, et al. Risk of retroviral infection among retrovirology laboratory and health care workers. American society for Microbiology 92nd general meeting, New Orleans, Louisiana, May 26-30, 1992. \{abstract T-20\}.

47. Electronic Therapeutic Guidelines. http://www.tg.org.au/etg_ demo/tgc/abg/4651.htm\#4703ID_GL.

48. Seegulam ME, Ratner L. Integrase inhibitors effective against human T-cell leukemia virus type 1. Antimicrob Agents Chemother 2011;55(5):2011-2017.

49. Haynes R, Ware E, Premanandan C, et al. Cyclosporine-induced immune suppression alters establishment of HTLV-1 infection in a rabbit model. Blood. 2010;115(4):815-823.

How to cite this article: Kaul DR, Sharma TS; on behalf of the AST ID Community of Practice. Human T-cell lymphotrophic virus in solid-organ transplant recipients: Guidelines from the American society of transplantation infectious diseases community of practice. Clin Transplant. 2019;33:e13575. https ://doi.org/10.1111/ctr.13575 